\title{
MODIFYING AND TESTING A HEADER SYSTEM FOR CEREAL CROP HARVESTER TO BE SUITABLE FOR SUNFLOWER HARVESTING
}

\author{
ABD EL MAKSOUD, M. A. F. ${ }^{1}$, G. H. EL SAYED ${ }^{2}$ AND S.A.H.M.SHALABY ${ }^{2}$
}

1 Ag. Eng. Dep., Fac. Of Ag., Menoufiya Univ

2 Ag. Eng. Res. Inst., ARC, Dokki, Giza

(Manuscript received 16 June 2009)

\begin{abstract}
Some essential parameters (header losses \%, length of cut neck $\mathrm{cm}$, head pulling before cutting \% and header efficiency \%) were measured in this investigation when harvesting sunflower crop at seed moisture content of 22.35, 15.15 and $10.75 \%$ wet basis , combine forward speed of 2.40, 2.82, 3.30, and3.80 km/hr, reaping direction with the directions: $d_{1}=\mathrm{N} \Leftrightarrow \mathrm{S}, \mathrm{d}_{2}=\mathrm{E} \rightarrow \mathrm{W}$, and $d_{3}=W \rightarrow E$. Based on these parameters, the header system for a cereal crops harvester (longitudinal axial-flow, with standard 5 bats reel (T) type CICORIA combine harvester was modified and tested. The demonstrated results for the tests showed that the suggested harvesting direction was $d_{1}$. Simultaneously, at all the investigated directions the moisture content of the sunflower seeds had a positive relationship with head pulling before cutting $\%$ and header efficiency \% while reversible correlation was found with the length of cut neck $\mathrm{cm}$ and the header losses $\%$. Also, both the header losses $\%$ and the head pulling before cutting $\%$ increased as increasing combine forward speed with the modifying header.
\end{abstract}

\section{INTRODUCTION}

Shafiullah et al. (2001) studied the effect of different row directions on yield and yield components of sunflower. They stated that using North-South and (NE-SW) row direction would help the crop to dry more quickly before harvest and reduce post harvest costs and losses.

Thierstein (1990) stated that shatter losses of combine header were significantly higher in rows planted east-west compared to rows planted north-east.

Trubilin and Kravchenko (2001) studied the feasibility of using the reaper units of Russian grain combines for the harvesting of sunflowers.

The results indicated that the reaper units should incorporate trough type separators, extra partitions between the central shaft of the reel and the rakes, and shields covering the rake tines. For normal cutting of the stems, the distance between the cutter unit and the lowest point of the reel should be not less than 200-250 mm. Reel diameter should be doubled, and the reel drive should ensure satisfactory cutting of the stems Griffin (1976) stated that the losses are pre-harvest loss, combine loss, (header, threshing, rack, shoe, and leakage loss). 
Kausal et al. (2003) reported that the field losses of the combine harvester increased with increasing cutter-bar height. The lowest field losses was obtained with a cutter-bar height of $(15 \mathrm{~cm})$ and at $(12-14 \%$ w.b) seed moisture content, when harvesting of sunflower.

Szendro and Szabo (1990) concluded that forward speed cannot be increased because of header losses when combine harvesters used for cereals can also be used for sunflower harvesting.

Dammermann and Wesche(1988) stated that more losses occur at the cutter bar rather than at the threshing, separation or cleaning stage when harvesting sunflowers by a standard combine harvester

Therefore, the objectives of this study were:

1- Modifying the header of the Cereal-Crop combine harvester to reduce its losses especially in case of the lodged plants by inclining the stem and cut the head only with minimum length of plant stalks.

2- Estimating the performance of the modified header device by using the combine harvester as a sunflower harvester.

\section{MATERIALS AND METHODS}

\section{The original combine harvester:}

The CICORIA combine harvester of cereal crops $(T)$ type, model longitudinal axialflow, with standard 5 bat reel, was used in this study after modifications as shown in Figure (1).

\section{The header modification procedure:}

1. Adding long and high seven (7) dividers, each divider with swivel lifter were attached to a long catch-pan with turned-up edges, as shown in Figure (2).The ends of the pans are fixed to the header up-on the cutter-bar. The aims of this modification step are to reduce both of the cutter-bar and the header losses

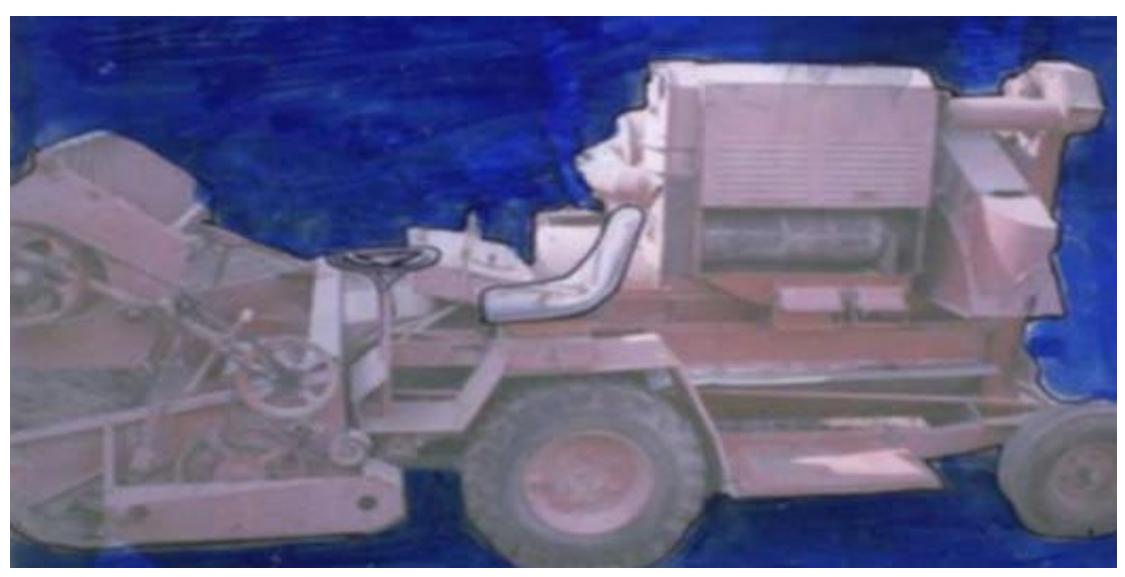

Figure (a): Combine harvester before modifications. 


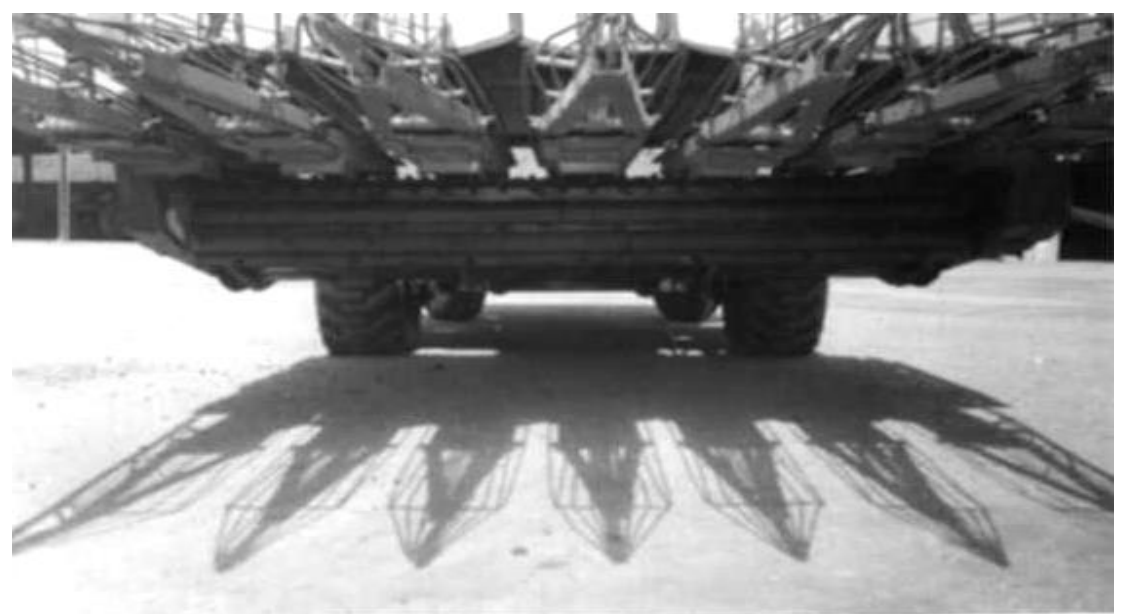

(b)

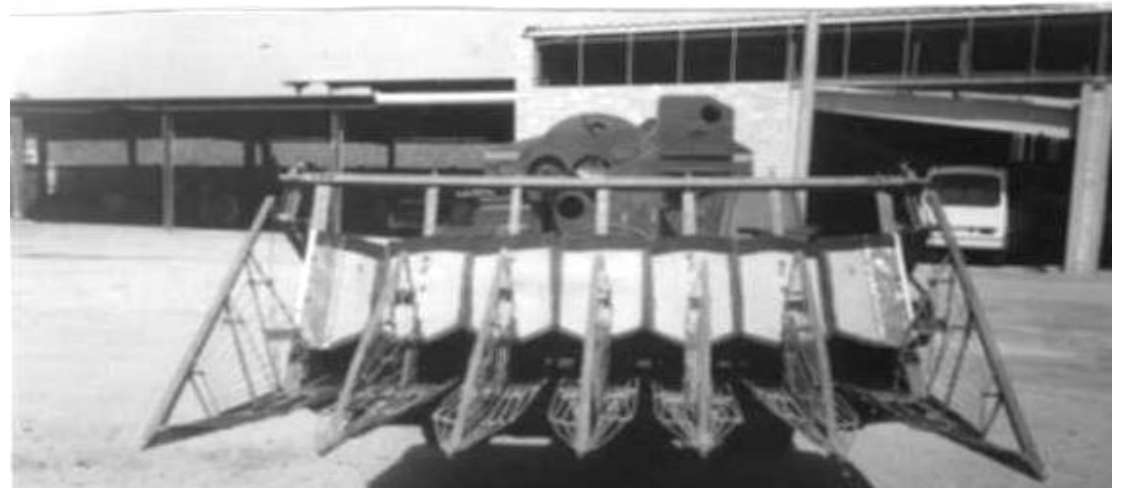

Figure (2): The modified header,

a, under the platform

$b$, under the platform 
(a)

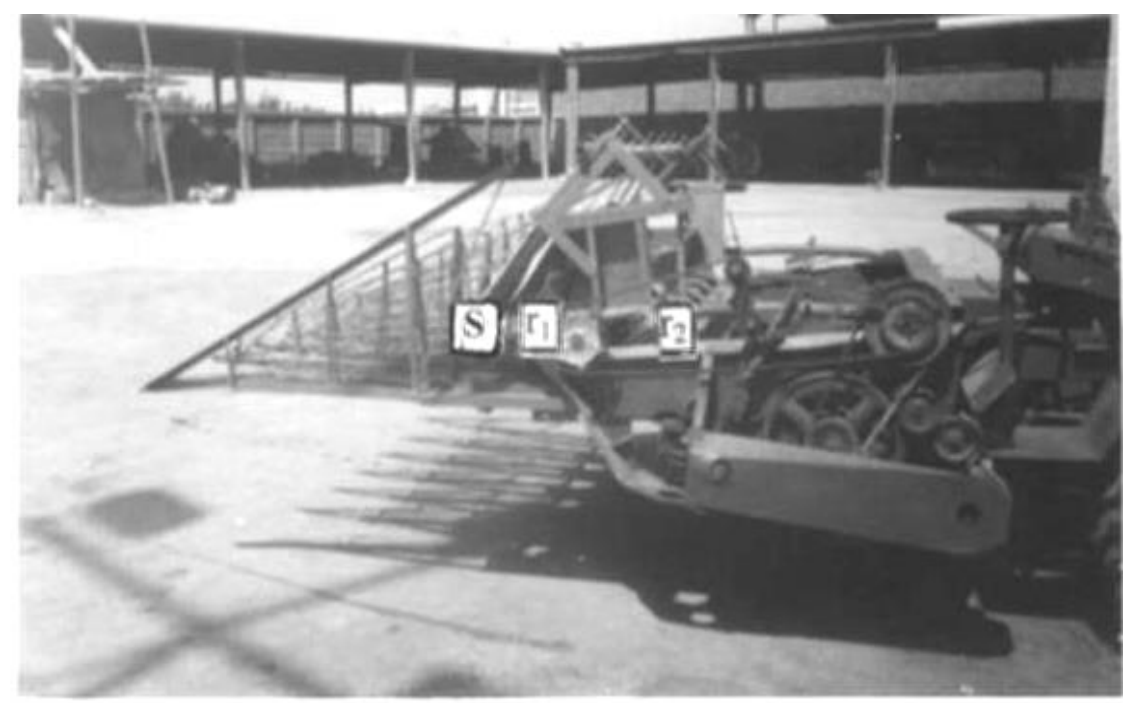

(b)

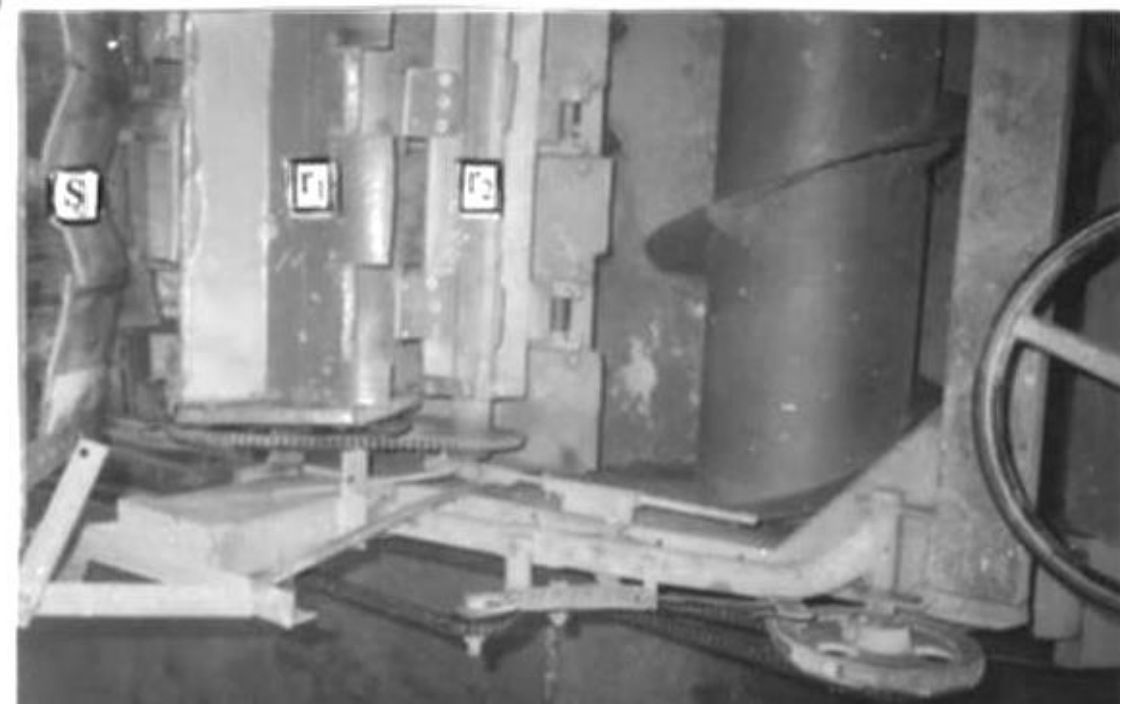

Figure 3. The shielded copying reels $\left(r_{1}\right.$ and $\left.r_{2}\right)$ and the rubber shield a-side view , b-plan. 


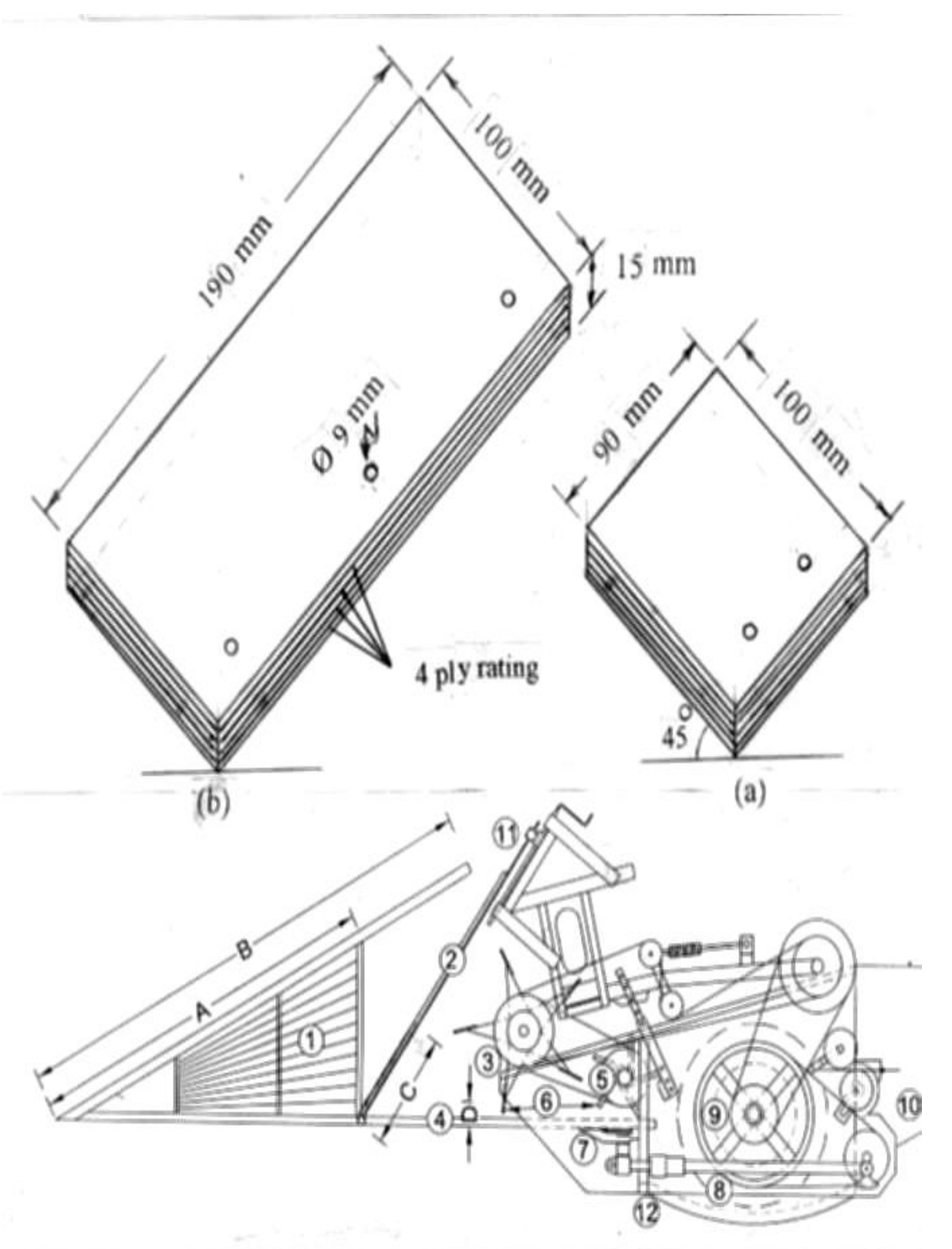

(Dims. in $\mathrm{mm}$ )

Figure 4. Schematic arrangement of the modified header and the rubber beaters for both front and back reels.

2. Replacement the original reel by twin shielded-copying reels, one of them is big, lays in front of the other that lays on the end of the platform (up-on the cutter-bar line) as shown in Figure (3).The motion of the back reel was taken from the front reel as the ratio of $1: 1$, while the speed of the front reel $(\mathrm{m} / \mathrm{s})$ which known as reel-index was from 1.1 to 1.2 of the machine forward speed. The aims of this step are to reduce the length of cut and increase the head-pulling percent. 
3. Displacement the cutter-bar position up-to a distance of $17 \mathrm{~cm}$ as shown in Figure (4).The aim of this step is to put a deflector (the lower deflector) to incline the stem and degenerate the head down to the catch-pans.

4. Adding a rubber shield and a deflector (the upper deflector), in frontage of the big reel (between the rear ends of the dividers and the front of the big reel) as shown in Figure (3).The aims of this step are to deflect the stem and to degenerate the head down to the catch-pans. The schematic arrangement of the modified header is shown in Figure (4).

1-Divider 2-Elastic shield 3-Front coping reel 4-Long grain pan 5-Back coping reel 6Coping beaters 7-Cutter bar 8-Pan of the collecting auger 9-collecting auger 10-Convayor 11-Upper deflector 12-Lower deflector A-Inner swivel B-Outer swivel C\&D-Adjustable clearances

\section{Measuring instruments:}

The following instruments were used in this study:

A. A common stop watch with 0.5 second accuracy was used to record the time spent during the execution of the reaping and harvesting operations.

B. An electric oven was used according to the ASAE standard (1992) to determine the seed moisture content, $130 \mathrm{C}$ for one hour after fractures the skin of seeds .

C. An electric balance with accuracy of $0.01 \mathrm{~g}$ and maximum $5000 \mathrm{~g}$. was used to determine the initial and the final weights of seed samples.

D. A $100 \mathrm{~kg}$ spring balance was used to weight the reaping and harvesting systems outputs with accuracy of $(0.50) \mathrm{kg}$.

E. A dial tachometer was used to measure the engine, rotor, reels, suction fan and winnowing speeds during the pre-experimental tests and the final

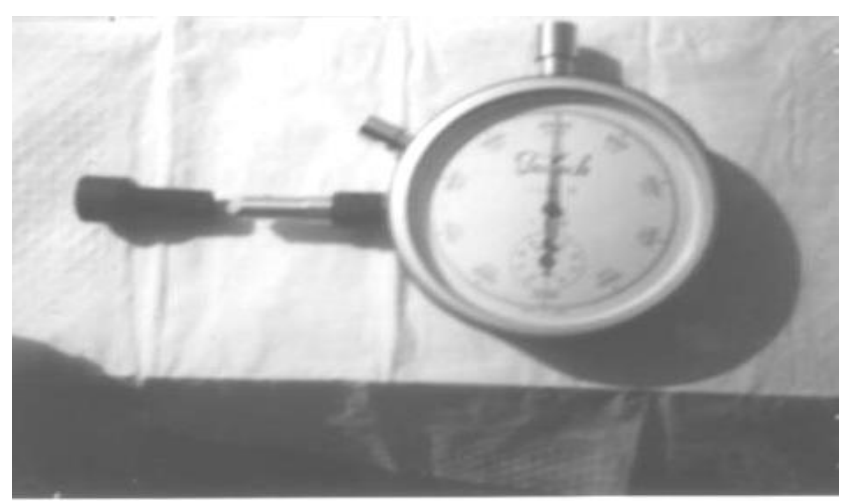

Figure 5. The dial tachometer(contact method) 

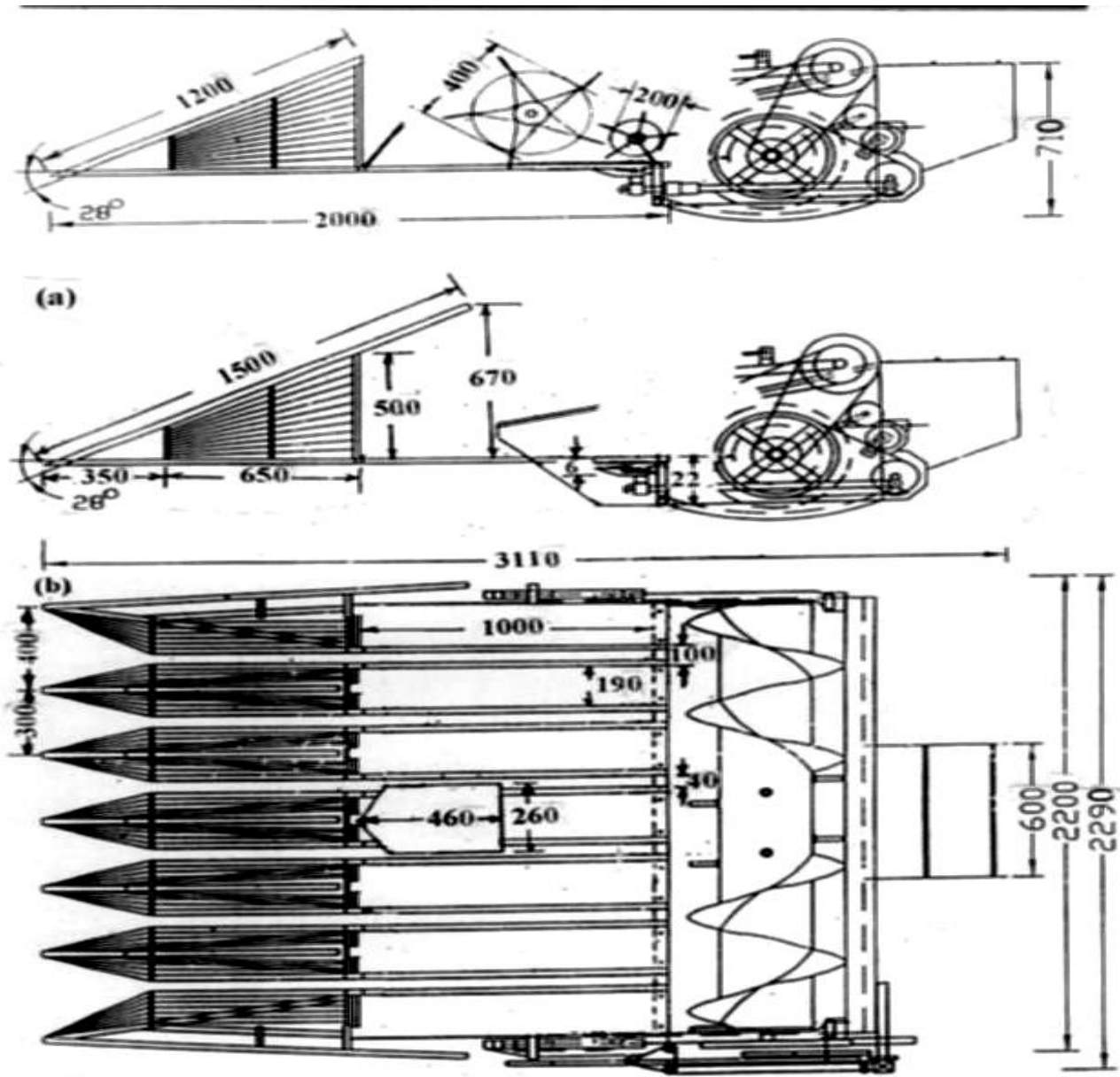

(c)

Figure (6-a, $b$ and $c)$ : The main dimensions of the modified header

(a) and (b) side view - (c) plan (Dims. in mm).

experimental measurements. Its range is from 0 to $10^{4}$ R.P.M. as shown in Figure (5) with an accuracy of $\pm 0.5 \%$.

F. An electric moisture tester Model $400 \mathrm{~B}$ was used to measure the seed moisture content directly.

\section{Adjustment of the modified device:}

The following adjustments were carried out at Gemmeiza Research Center workshop and research farms on CICORIA combine harvester for the pre-experimental adjustments:

a. Adjustment and determining the optimum distance between two dividers, as shown in Figure (6-c).

b. Adjustment and determining the optimum dimensions, speeds, positions and clearance ratios of the big and the small reels, Fig. (8a).

c. Adjustment and determining the optimum length, width and height of the divider, as shown in Figure (6-b). 
d. Adjustment and determine the optimum width, length, height and position of the rubber shield and the upper deflector, Figure (6- c).

e. Adjustment and determining the positions of the cutter-bar and the lower deflector as shown in Figure (6-c).

f. Determining the optimum harvesting direction in which the lowest reaping losses were conducted as shown in Figure (7).

\section{Factors affecting the header performance and their levels:}

-Seed moisture content (MC), with the levels: $22.35,15.15$ and 10.75 (\%wet basis).

-Combine forward speed (S): 2.40, 2.82, 3.30, and3.80 km/h.

-Reaping direction (D), with the directions: $d_{1}=N \Leftrightarrow S$, $d_{2}=W \leftarrow E$, and $d_{3}=$ $\mathrm{E} \leftarrow \mathrm{W}$

To determine the effects of these factors, the following parameters were taken: header losses $(\%)$, length of cut neck $(\mathrm{cm})$, head pulling before cutting $(\%)$ and calculated header efficiency (\%).
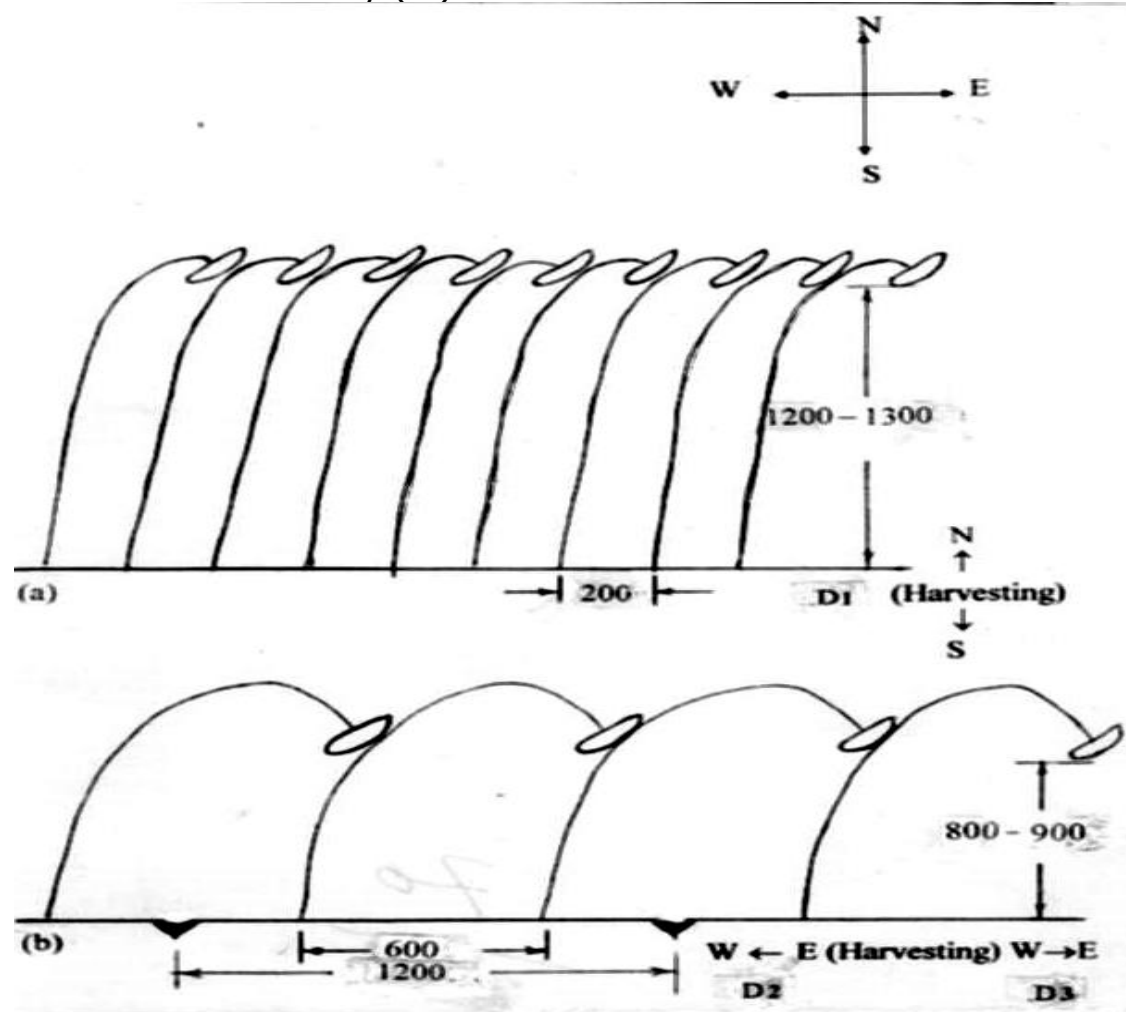

Figure 7. The suggested harvesting directions:

$$
D_{1}=N \Leftrightarrow S, D_{2}=E \rightarrow W \text { and } D_{3}=W \rightarrow . E
$$

Methods of measurements:

Measurement of factors:

a. Seed moisture content, ( $\%$ wet basis):

It was measured on harvesting day by two methods.

1. Directly, by using electric moisture tester Model $400 \mathrm{~B}$. 
2. The drying method by using an electric oven according to the ASAE standard $\left(130^{\circ} \mathrm{C}\right.$ for 1 hour).

The treatments on moisture samples were determined using the oven method to check the electric tester. The differences between the two methods were about \pm $0.2 \%$.

MC (\%w.b) $=\frac{\text { Sample weight before drying }- \text { sample weight after drying }}{\text { sample weight before drying }}$

\section{b. Combine forward speed, (S), $\mathrm{m} / \mathrm{s}$ :}

The combine forward speeds were measured during harvesting operation using a digital stop watch to record the time needed for travel a distance of thirty five meters long. The lost time as in turning, repairing and cleaning was recorded also $\mathrm{S}=\frac{\operatorname{distance}(\mathrm{m})}{\text { time } \operatorname{spent}(\mathrm{sec})}=\mathrm{m} / \mathrm{s}$

\section{c. harvesting directions, (D),}

Generally, the harvesting operations were done perpendicular to sowing direction in order to redeem the action of stem lodging

\section{Measurements of the modified header performance:}

\section{a. Seed losses:}

\section{Pre-harvesting losses:}

It represents seeds on the ground before combine passage. The average seed losses $\mathrm{g} / \mathrm{m}^{2}$ were determined by locating a wooden frame with area $(50 \times 200) \mathrm{cm}^{2}$ in a typical un harvested area of the field. The percentage of pre-harvest losses was calculated using the following equation:

Pre-harvest losses $\%=\frac{\text { Weight of seed on the ground } \mathrm{g} / \mathrm{m}^{2}}{\text { Total yield } \mathrm{g} / \mathrm{m}^{2}} \times 100$

\section{Header losses:}

Header losses were determined by locating two collecting pans with area (50 x 100) $\mathrm{cm}^{2}$ between plant rows. The material shattered by header was collected in the pans and backed in bags. Three replicates were randomly done for each treatment. The total collected seeds were cleaned and weighed. The cut and uncut heads were collected, threshed and cleaned manually and then weighed. The total weight of seeds collected as losses from the specific area was related to the total seed yield from that area. The header losses could then be obtained from the following relation, Header losses $\%=\frac{\text { Weight of seeds lost by header } \mathrm{g} / \mathrm{m}^{2}}{\text { Total weight of seed yield } \mathrm{g} / \mathrm{m}^{2}}$

(These measurements were done while the machine was traveling at a constant speed over measured and timed distance).

3-Reaping efficiency (\%) $=100$-header losses. 


\section{RESULTS AND DISCUSSION}

\section{The performance of the modified reaping system:}

Figure (8- A, B and C) shows the reaction between the modified header and the position of both head and its neck according to the harvesting directions. It is shown that the direction of $\left(D_{1}\right)$ determined as optimum direction for decreasing header losses because this direction is perpendicular to the inclined direction of stems either from North to South or in the reverse direction (Figure8- A). Applying $D_{1}$, the swivel lifters as shown in Figure (4) previously are lifting both standing or fallen and logged plants. The forward motion by the machine, facilitating the relief of the terrain to the copying reels.

Effect of forward speed (S), moisture content (MC) and harvesting direction (D) on header losses, \% and efficiency \%:

\section{Forward speed:}

Figure (9-A) shows that increasing forward speed from 2.4 to $3.8 \mathrm{~km} / \mathrm{h}$ increased header losses from 0.51 to $1.83 \%$ under harvesting at seed moisture content of 22.35 $\% w . b$. in the direction of $D_{1}$. The same trend was occurred associated with more increase in header losses when harvesting in the directions $D_{2}$ or $D_{3}$, respectively.

The increment in header losses while increasing forward speed is due to the excessive load on the cutter-bar and the excessive knocking of twin reels specially when harvesting in the direction $D_{3}$ because the direction $D_{3}$ is the same direction of stem inclining, so that, some of heads tend to go down to the soil surface before catching by dividers causing more header losses and low header efficiency as shown in Figure (9- B).

\section{Moisture content:}

The effect of seed moisture content on header losses is shown in Figure (9-A) It is noted that decreasing the harvesting seed moisture content from 22.35 to10.75\% w.b at forward speed of $2.4 \mathrm{~km} / \mathrm{h}$ in the direction $D_{1}$ increased header losses from 0.51 to $2.27 \%$. So, the moisture content of $22.35 \%$ w.b is recommended for decreasing header losses and increasing the reaping efficiency as shown in Figure (9-B). The same trend of results is obtained when harvesting in $D_{2}$ or $D_{3}$ direction and at the all levels of forward speed with more increase in header losses.

The increment of header losses as decrement moisture content is due to the lower moisture content than $22.35 \%$ w.b which make seeds can be separated easily from the outer rounds of heads by shaking stems and the stem with heads can be broken easily when bending to the direction of the forward speed, especially when harvesting in the third direction of $d_{3}$ and at high forward speed, as shown in Figure (8-A, B and C). 


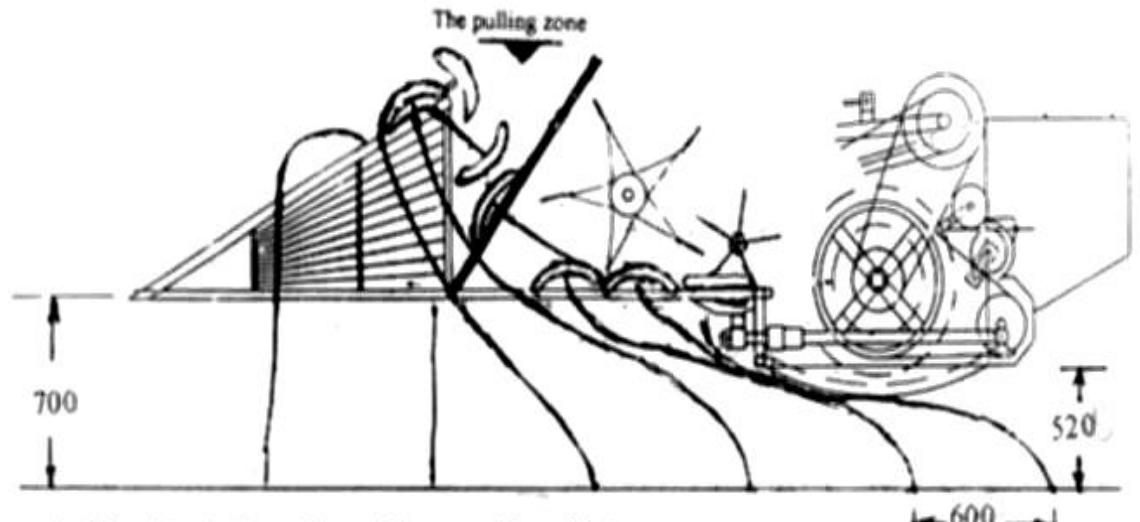

A. The first direction of harvesting $\left(D_{1}\right)$ :

Header losses $\%^{*}$, length of neck $(\mathrm{cm})^{\circ}$, disk pulling $\% \cdots$

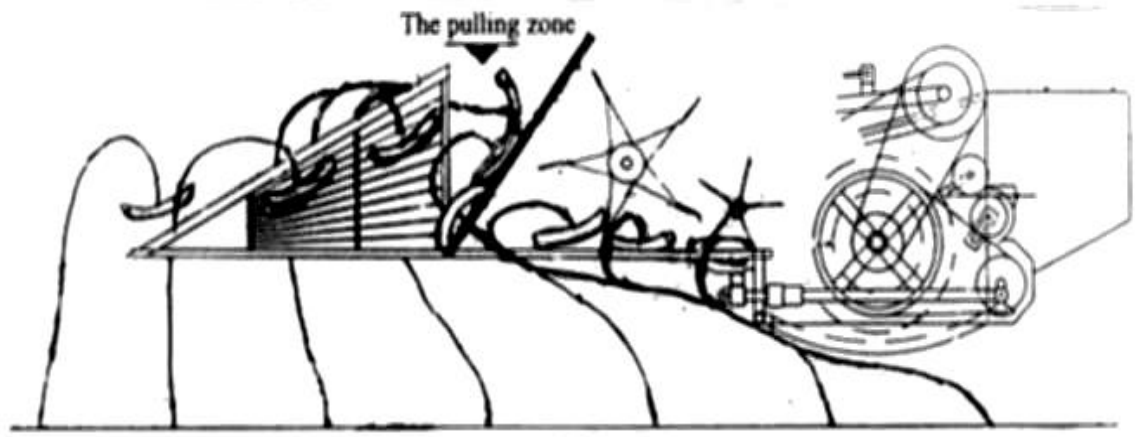

B. The second direction of harvesting $\left(\mathrm{D}_{2}\right)$ :

Header losses $\%{ }^{*}$, length of neck $(\mathrm{cm})^{* \bullet}$, disk pulling $\%{ }^{\bullet \bullet}$

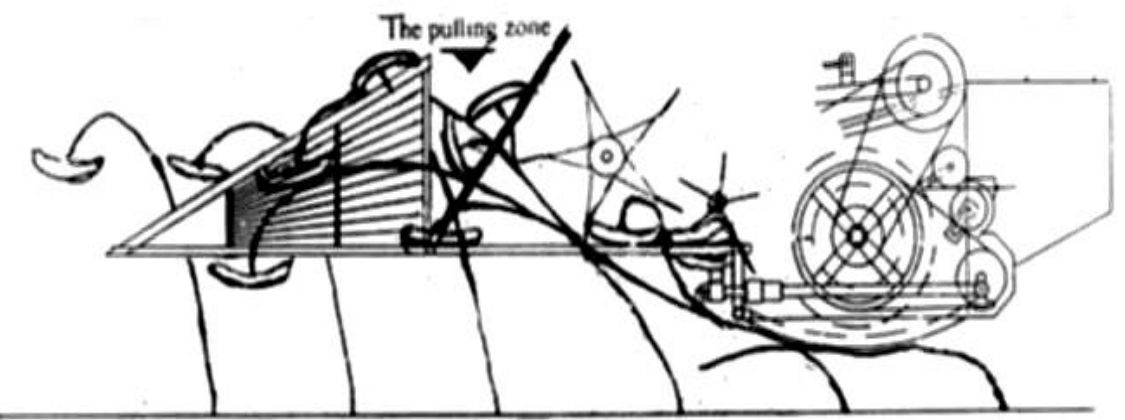

C. The third direction of harvesting $\left(D_{3}\right)$ :

Header losses $\% *{ }^{* \bullet}$, length of neck $(\mathrm{cm}){ }^{* * *}$, disk pulling $\%{ }^{\bullet}$

Figure (8-A, B and $C$ ): The reaction between the modified header and the position of both head and its neck to the harvesting directions.

$*$-law value $* *$ middle value $* * *$ high value

While the amount of header losses when harvesting at high stage of moisture content more than $15.15 \%$ w.b is due to the elasticity of stalks which causes its bending to the reaping direction, so that, the heads go down or far from catching by dividers especially when harvesting in the direction $D_{3}$ or at high forward speed. 


\section{Harvesting direction:}

Figure (9- A) shows that when harvesting at seed moisture content of $10.75 \%$ w.b and forward speed of $3.8 \mathrm{~km} / \mathrm{h}$ in the direction $D_{1}$, the header losses were 3.59 $\%$, while these losses increased to $4.17 \%$ when harvesting in the direction $D_{2}$. Meanwhile, the header losses were $4.84 \%$ (62.29 kg/fed.) when harvesting in the direction $D_{3}$, at the same previous conditions. This result means that header losses and reaping efficiency (Figure 9-B) are affected by reaping direction. The same trend of results is occurred with lower increment in header losses when harvesting at moisture content of 15.15 or $10.75 \%$ w.b by the same combine forward speed. As shown in Figure (8- A, B and $C$ ), this results is due to the differences between the three directions in both of the position and direction of feeding of the head and its neck, these differences may be explained as following:

The first difference lies between $D_{1}$ (Figure 8- $A$ ) and both of $D_{2}$ (Figure8- B) and $D_{3}$ (Figure8- $C$ ). This difference is in the position of head and its neck, (or its curved neck), in front of the pan, the position of head in the first direction $D_{1}$ is: its face upward and its neck downward, while its position in both of $D_{2}$ and $D_{3}$ is: its face downward and its curved neck upward.

The second difference lies between the two directions $\left(D_{2}\right.$ and $\left.D_{3}\right)$. This difference is in the arrangement of feeding, in the second direction $D_{2}$, the head is fed in the front (early) and its curved neck is fed in back (late), while, in the third direction $D_{3}$, the curved neck is fed in the front (early) and the head is fed in the back (late) ,Figure (8- B and C). A multi regression analysis was conducted to clarify the previous results obtained. The regression equations are as follows: 
At $22.35 \%$ seed Mc
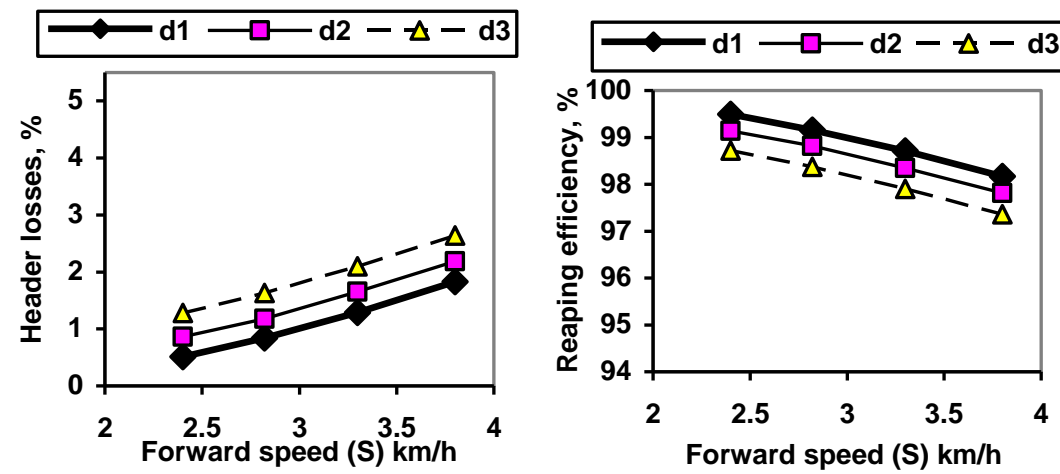

At $15.15 \%$ seed Mc
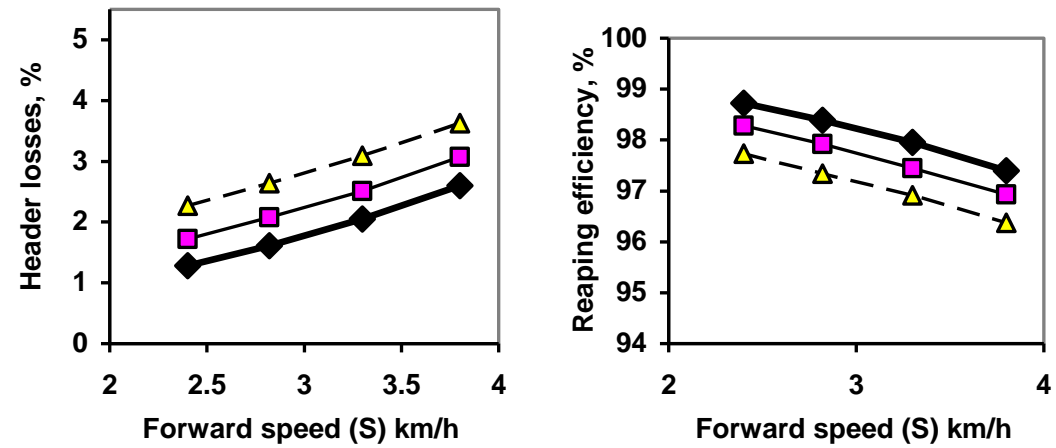

At $10.75 \%$ seed Mc

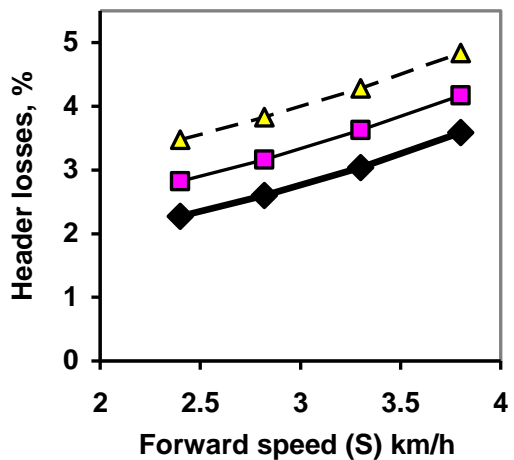

(9-A)

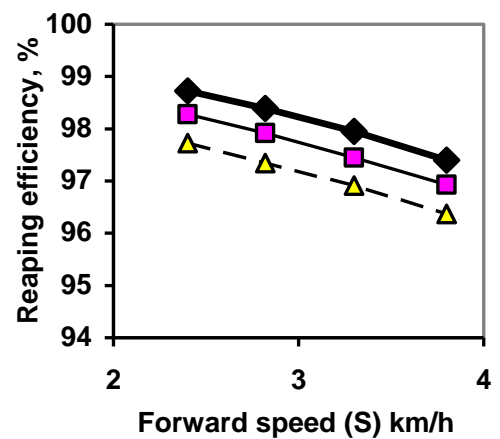

(9-B)

Figure: (9-A, B): Effect of harvesting forward speeds on header losses and efficiency at different harvesting directions and seed moisture

For direction $\left(D_{1}\right): H L, \%=1.17-0.146 M C \%+0.979 S \quad\left(R^{2}=0.82\right)$

For direction $\left(D_{2}\right): H L, \%=1.40-0.136 \mathrm{MC} \%+0.989 \mathrm{~S} \quad\left(\mathrm{R}^{2}=0.88\right)$

For direction $\left(D_{3}\right): H L, \%=2.10-0.126 M C \%+0.999 S \quad\left(R^{2}=0.89\right)$.

Where:

$\mathrm{HL}, \%=$ percent of header loss,

MC, \% = percent of Moisture Content wet basis,

$\mathrm{S}=$ Forward speed, $\mathrm{km} / \mathrm{h}$. 
Also, the following regression equations revealed that there are effective differences between means of the reaping efficiency as affected by different levels of both seed moisture content, machine forward speed and harvesting direction:

$\begin{array}{lll}\text { For } \mathrm{D}_{1}: H \mathrm{H}_{1} \%=99.8+0.0671 \mathrm{MC} \%-0.937 \mathrm{~S} & \left(\mathrm{R}^{2}=0.88\right) \\ \text { For } \mathrm{D}_{2}: H \mathrm{H}_{1} \%=99.1+0.0702 \mathrm{MC} \%-0.955 \mathrm{~S} & \left(\mathrm{R}^{2}=0.81\right) \\ \text { For } \mathrm{D}_{3}: \mathrm{HE} \%=98.56+0.0739 \mathrm{MC} \%-0.970 \mathrm{~S} & \left(\mathrm{R}^{2}=0.82\right)\end{array}$

Where: H.E, \% = Header efficiency, $M C, \%=$ Percent of seed moisture content wet basis, $\mathrm{S}=$ forward speed $(\mathrm{km} / \mathrm{h})$.

Effect of forward speed (S), moisture content (MC) and harvesting direction (D) on Length of neck cut, cm:

\section{Forward speed:}

Data in Table (1) show that the length of neck is affected by reaping forward speed. Increasing forward speed from 2.4 to $3.8 \mathrm{~km} / \mathrm{h}$ at harvesting seed moisture content of $22.35 \%$ w.b in the direction $\mathrm{D}_{3}$ showed decreasing in the length of neck from 24 to $12 \mathrm{~cm}$. This trend of result is occurred with more decrease in length of neck when harvesting in the $D_{2}$ or $D_{1}$ directions. As shown in the Table, the decrement in length of neck by increasing the forward speed is due to the excessive traction (or draft or pulling) on stem while increasing the forward speed, so that, short neck with head will fed into the first copying reel and then cut under the second copying reel which deliver the heads to the collecting auger.

Table 1. Effect of combine forward speed (S), reaping direction (D) and seed moisture content $(\mathrm{MC})$ on the performance of the modified reaping system

\begin{tabular}{|c|c|c|c|c|c|c|c|c|c|c|c|c|c|}
\hline \multirow{3}{*}{$\begin{array}{l}\text { SEED } \\
\text { M.C. } \\
\% \text { w.b. }\end{array}$} & \multirow{3}{*}{$\begin{array}{c}\text { FWD } \\
\text { speed (S) } \\
\mathrm{km} / \mathrm{h} \\
\end{array}$} & \multirow{2}{*}{\multicolumn{3}{|c|}{\begin{tabular}{|c} 
Header losses, \\
$\%$
\end{tabular}}} & \multirow{2}{*}{\multicolumn{3}{|c|}{$\begin{array}{l}\text { Length of cut } \\
, \mathrm{cm} \\
\text { Reaping direction } \\
\text { (D) }\end{array}$}} & \multirow{2}{*}{\multicolumn{3}{|c|}{\begin{tabular}{|c|} 
Disc pulling, \% \\
Reaping direction \\
$(\mathrm{D})$ \\
\end{tabular}}} & \multirow{2}{*}{\multicolumn{3}{|c|}{$\begin{array}{l}\text { header efficiency, \% } \\
\text { Reaping direction } \\
\text { (D) }\end{array}$}} \\
\hline & & & & & & & & & & & & & \\
\hline & & $\mathrm{D}_{1}$ & $D_{2}$ & $D_{3}$ & $\mathrm{D}_{1}$ & $D_{2}$ & $\mathrm{D}_{3}$ & $\mathrm{D}_{1}$ & $\mathrm{D}_{2}$ & $\mathrm{D}_{3}$ & $\mathrm{D}_{1}$ & $\mathrm{D}_{2}$ & $\mathrm{D}_{3}$ \\
\hline \multirow{4}{*}{$\begin{array}{c}M_{1} \\
22.35\end{array}$} & 2.40 & 0.51 & 0.86 & 1.28 & 9 & 16 & 24 & 36 & 27 & 17 & 99.49 & 99.14 & 98.72 \\
\hline & 2.82 & 0.84 & 1.18 & 1.63 & 8 & 14 & 21 & 40 & 30 & 19 & 99.16 & 98.82 & 98.37 \\
\hline & 3.30 & 1.29 & 1.65 & 2.10 & 6 & 11 & 17 & 43 & 33 & 21 & 98.71 & 98.35 & 97.90 \\
\hline & 3.80 & 1.83 & 2.19 & 2.64 & 2 & 7 & 12 & 46 & 35 & 22 & 98.17 & 97.81 & 97.36 \\
\hline \multirow{4}{*}{$\begin{array}{c}M C_{2} \\
15.15\end{array}$} & 2.40 & 1.28 & 1.72 & 2.27 & 13 & 21 & 31 & 29 & 20 & 9 & 98.72 & 98.28 & 97.73 \\
\hline & 2.82 & 1.61 & 2.08 & 2.64 & 12 & 19 & 28 & 32 & 22 & 10 & 98.39 & 97.92 & 97.34 \\
\hline & 3.30 & 2.05 & 2.51 & 3.09 & 10 & 16 & 24 & 3 & 24 & 11 & 97.95 & 97.45 & 96.91 \\
\hline & 3.80 & 2.60 & 3.07 & 3.63 & 7 & 12 & 19 & 3 & 25 & 12 & 97.40 & 96.93 & 96.37 \\
\hline \multirow{4}{*}{$\begin{array}{c}\mathrm{MC}_{3} \\
10.75\end{array}$} & 2.40 & 2.27 & 2.82 & 3.48 & 18 & 26 & 39 & 21 & 11 & 3 & 97.70 & 97.18 & 96.52 \\
\hline & 2.82 & 2.60 & 3.16 & 3.83 & 16 & 24 & 38 & 25 & 13 & 6 & 97.40 & 96.84 & 96.17 \\
\hline & 3.30 & 3.04 & 3.63 & 4.28 & 13 & 20 & 34 & 28 & 17 & 8 & 96.96 & 96.34 & 95.72 \\
\hline & 3.80 & 3.59 & 4.17 & 4.84 & 10 & 16 & 26 & 30 & 18 & 10 & 96.41 & 95.83 & 95.16 \\
\hline
\end{tabular}




\section{Moisture content:}

It is obvious from data in the Table that the length of neck significantly increased from $9 \mathrm{~cm}$ to $18 \mathrm{~cm}$ when the moisture content of the harvested crop decreased from 22.35 to $10.75 \%$ w.b.at forward speed of $2.4 \mathrm{~km} / \mathrm{h}$ in the direction of $D_{1}$. So that, the moisture content of $22.35 \%$ is recommended for decreasing the length of neck. As sunflower stay longer in the field for reducing moisture content as a longer part of stem is bent (long curved neck) and the head become beneath. In this case the heads will be logged and some of them lost whilst harvesting, especially when harvesting in the direction of $D_{3}$, Figure (8- C). These conditions of bending cause a longer neck to be cut, by meaning that as sunflower stay longer in the field as length of neck be longer.

\section{Harvesting direction:}

The observed data in Table (1) show that when harvesting at seed moisture content of $10.75 \%$ w.b. and forward speed of $3.8 \mathrm{~km} / \mathrm{h}$ in the direction of $D_{3}$, the length of neck is $26 \mathrm{~cm}$, while the lengths of 16 and $10 \mathrm{~cm}$ were occurred when harvesting in the directions $D_{2}$ and $D_{1}$, respectively. These results mean that the shortest neck may be obtained when harvesting in direction $D_{1}$, while the longest neck may be obtained when harvesting in the direction of $D_{3}$.As shown in Figure (8- $A, B$ and $C$ ), these results may be due to the interaction between the factors of moisture content and the harvesting direction in comparison with the inclining direction of the stem. Whilst harvesting in the direction $D_{1}$ (whilst forward motion by the machine), the front end of the swivel-lifter of the divider can penetrate the lodged plant and also lifts the fallen plants and gather them into a bunch and properly follow the relief of the terrain. During this operation, and at the rear end of the swivel lifter, the head takes a position where its face upward (vertically) while its neck be down (horizontal). The head with this special position crosses the shield and is delivered as it is to the first copying reel which delivers it to the second copying reel that press on the head surface down to the pan causing a shortest neck to be cut by the cutter bar knives. In the harvesting direction $D_{2}$ or $D_{3}$, the head delivers between every two dividers as it is, its face downward (horizontal) and its long curved neck is bent upward (vertically). The head with its long curved neck crosses the shield and is delivered to the first copying reel which presses the curved neck down through the path between two pans, (with the elastic bats), and press the head down to the pan (its face is downward and its curved neck upward). The plant stalks pressed by the direct pressure of the bats as the latter revolve, press on the nearest successive plants which, in turn, react on the next once, etc. In this way is formed a wave of density of bent plants proceeding toward the cutting bar beneath the second copying reel. 
The regression analysis of data clarified the inverse relationship for both seed moisture content and machine forward speed towards the length of cut neck at the concerned harvesting direction. The following regression equations revealed the effective differences in length of neck as affected by the harvesting direction under different levels of seed moisture content and harvesting forward speed:

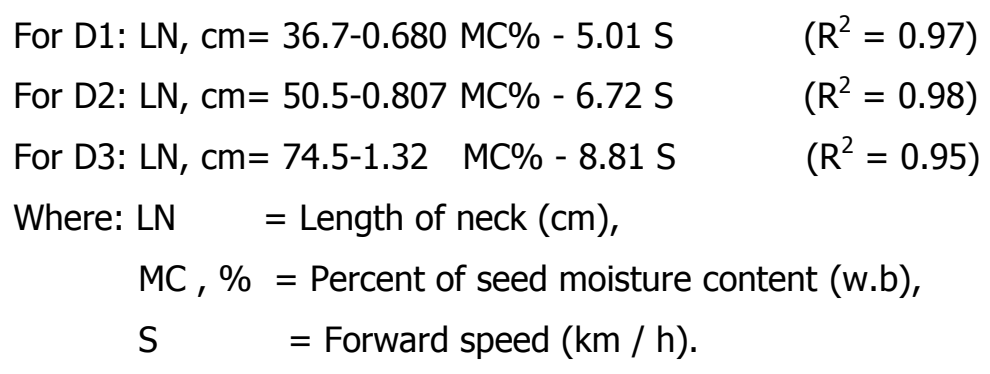

Effect of forward speed (S), moisture content (MC) and harvesting direction (D) on disk pulling \%( before cutting):

\section{Forward speed}

It is obvious from Figure (10) that increasing forward speed from 2.4 to $3.8 \mathrm{~km} / \mathrm{h}$ when harvesting in the direction $\mathrm{D}_{3}$ and seed moisture content of $22.35 \%$ w.b. increased the percentage of the pulled disks from 17 to $22 \%$. More increments in percentage of pulled disks were occurred in the directions $D_{2} \circ D_{1}$. As shown in Figure (8- A, B and C), the different increments in percentage of the pulled disks by increasing the forward speed is due to the differential traction (pulling) on head while increasing the forward speed owing to the position of the disk in front of the pan, (as shown in Figure 8 - A) whereas non curved neck, when the disk be pulled, there would be no neck with the head. In case of harvesting in the direction $D_{2}$ (Figure8- B) whereas the head is in front of feeding position (early) and the curved neck in backward (late), the cutter knife cuts the curved neck while it be pressed down by the small copying reel. So, the ratio of pulling disk without neck is lower than that in the direction $D_{1}$. While in case of harvesting in the direction $D_{3}$ (Figure $8-C$ ), whereas the curved neck is in the front position (early) and the head in backward (late), the cutter knife cuts the curved neck before the head be pressed down by the small copying reel. So, the ratio of pulling disk without neck is lower than that in the second direction $\mathrm{D}_{2}$ (Figure 8- $\mathrm{B}$ ).

\section{Moisture content:}

It is clear from Figure (10) that the decrement of moisture content from 22.35 to $15.15 \%$ resulted in slight decreasing of the pulled disks from 17 to $9 \%$ when harvesting by forward speed of $2.4 \mathrm{~km} / \mathrm{h}$ in the direction $D_{3}$, while further decreasing of moisture content from 15.15 to $10.75 \%$ caused slight decreasing in pulled disks from 9 to $3 \%$ at the same conditions. As shown in Figure (8- A, B and C), this result is due to the fact that: as sunflower stay longer in the field, with the passage of time, 
the length of the bent stem is longer and so the head will be beneath. This position causes a long curved neck with head at the position of feeding by the small copying reel and while cutting by the cutter knife.

\section{Harvesting direction:}

The represented data in Figure (10) clear that when harvesting at moisture content of $10.75 \%$ by forward speed of $3.8 \mathrm{~km} / \mathrm{h}$ at the direction of $D_{1}$, the percentage of pulling disks is $30 \%$, while the percentage of 18 and $10 \%$ were occurred when harvesting by the same forward speed in the directions $D_{2}$ and $D_{3}$ respectively. This result means that the lower percentage of pulling may be obtained by harvesting in the direction of $D_{3}$, while the higher percentage may be obtained by harvesting in $D_{1}$ direction. This result is due to the differences between the directions in both position and direction of feeding of the head and its neck.

The same trend of results was occurred by the regression analysis. The following regression equations show that there are effective differences between the percent of the disk pulling $\%$ as affected by the harvesting directions under the different levels of both seed moisture content $\%$ and machine forward speed:

$\begin{array}{lll}\text { For D1: DP, \% }=-6.96+1.29 \mathrm{MC} \%+6.38 \mathrm{~S} & \left(\mathrm{R}^{2}=0.98\right) \\ \text { For D2: DP, \% }=-14.6+1.4 \mathrm{MC} \%+4.89 \mathrm{~S} & \left(\mathrm{R}^{2}=0.97\right) \\ \text { For D3: DP, \% }=-17.1+1.16 \mathrm{MC} \%+3.46 \mathrm{~S} & \left(\mathrm{R}^{2}=0.98\right)\end{array}$

Where: D.P, $\%=$ Percent of disk pulling,

$\mathrm{MC}, \%=$ Percent of seed moisture content (w.b),

$\mathrm{S} \quad=$ forward speed $(\mathrm{km} / \mathrm{h})$.

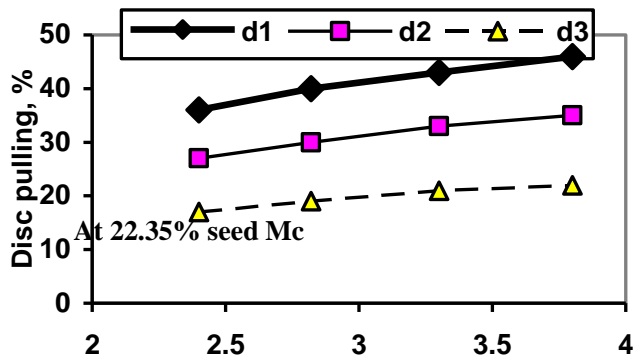

Forward speed (S) km/h
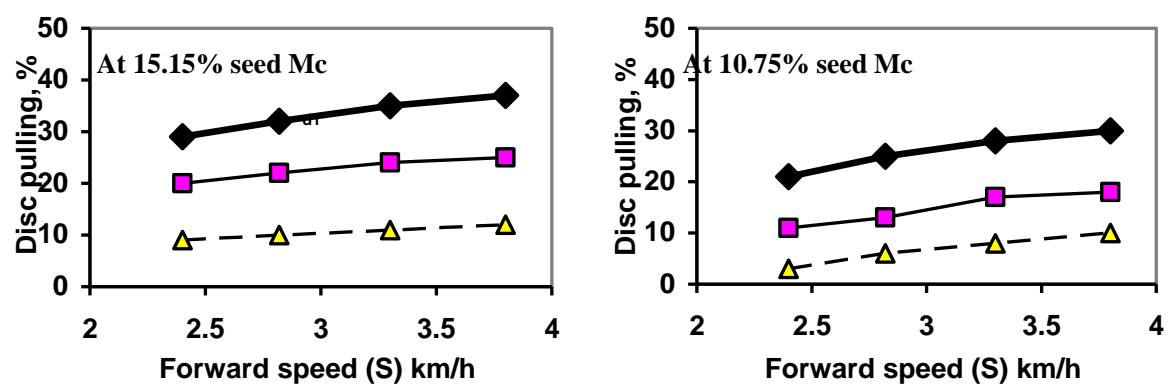

Figure 10. Effect of harvesting forward speed on disk pulling at different harvesting directions and seed moisture contents. 


\section{REFERENCES}

1. ASAE. 1992. Standard, S352.2, Moisture measurement-unground grain And seeds. St. Joseph: American Society of Agricultural Engineering.

2. Dammermann, M. and H. Wesche. 1988. Special crop harvest with minimum losses. Claas OHG, Postfach 11 40, 4834 Harsewinkel, German Federal Republic. Landtechnik-. 1988, 43(6): 257-260 .

3. Griffin, G.A. 1976. Fundamentals of machine operations combine harvesting, John Deer Service Publication, p. 134-156.

4. Kausal, R.T., B.N. Patil,, S.R. Kadam and N.R. Pavitrakar. 2003. Case study on harvesting and threshing methods of sunflower and safflower. Seed Technology Research Unit, Dr.Panjabrao Deshmukh Krishi Vidyapeeth, Akola, 444104 (M.S.), India. Annals-of-Plant-Physiology. 2003, 17(1): 34-38

5. Shafiulah, M.A., M.A. Khan, B.R. Baitullah, C.A. Rana, Khan and Ozair. 2001. Effect of desiccant application and time of harvest on yield and oil quality of sunflower. J. National Agric. Res. Center, Pakistan. Helia, 2001, 24: 34, 105-113, 13 ref.

6. Szendro, P. and I. Szabo. 1990. Reduction of the loss of sunflower harvesting. University of Agriculture, Godollo, Hungary. Hungarian-AgriculturalEngineering. 1990, ( 3): 20-21

7. Thierstein, G.E. 1990. Header loss in harvesting sunflowers. Dept. of Agricultural Engineering, Kansas State University, American-Society-of-Agricultural-Engineers. 1990 ( 90-6049): 12 pp.

8. Trubilin,.E.I. and V.S. Kravchenko. 2001. The feasibility of harvesting sunflower with the reaper units of grain combines. : Tekhnika-v-Sel'-skom-Khozyaistve. 2001, (1): 20-22. Moscow, Russia: Mezhdunarodnyi Tsentr Nauchnoi i Tekhnicheskoi Informatsii. 
تعديل و اختبار مقدمة ألة حصاد الحبوب الجامعة لتناسب

حصاد محصول عباد الشمس

محمد عبد الفتاح عبد المقصود'، جمال حسن السبد` ، سمير عبد الحميد مصطفى شلبى؟

ا قسم الهندسة الزراعية - كلية الزراعة - جامعة المنوفية.

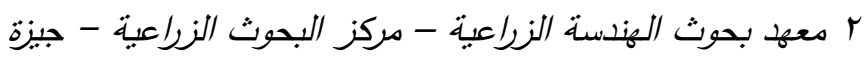

أجرى هذا البحث بغرض إدخال تعديل مناسب علي جهاز الحصاد (المقدمة ) في كومباين أوربى صمم خصيصا لحصاد محاصيل الحبوب الصغيرة حتى يناسب حصـاد أقراص محصول عباد الثمس. لذللك فإن الكومباين ماركة شيكوريا من النوع على شكل حرف (T) ، موديل سريان محوري طولي ذو مضرب ضم يحتوى على خمسة مضارب قد استخدم في إتمام هذه الدراسة بعد تعديله. وقد اشتملت عملية التعديل على الآتي: تعديل مقدمة الحصاد بغرض تقليل فاقد المقدمة وذللك بتقليل طول الجزء المقطوع من الساق مع القرص والحصاد بقدر الإمكان فى مستوى رطوبة داخل الحبوب عال نسبيا. وكذلك بغرض زيادة كفاءة الحصاد ونسبة نزع الأقراص.

تم زراعة مسـاحة التجربـة بصنف عباد الثمس فيدوك وهو هجين لإنتاج الزيت واستخدمت آلة

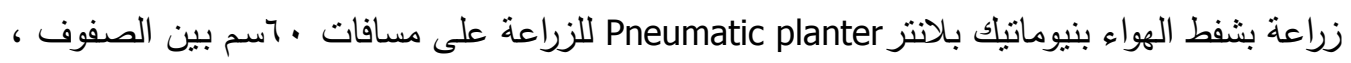

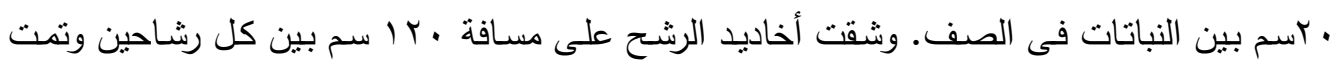
الزراعة فى اتجاه عمودي على اتجاه الحصاد.

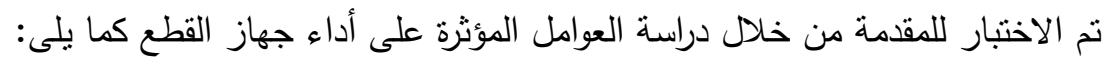

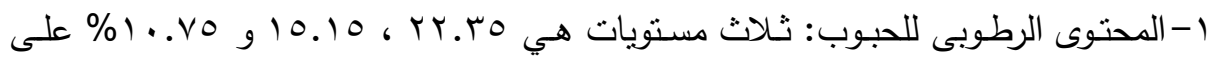

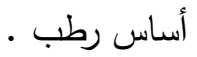

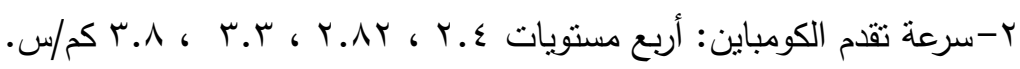

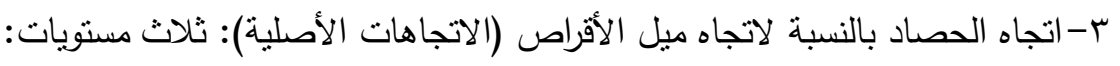

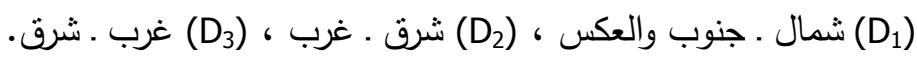

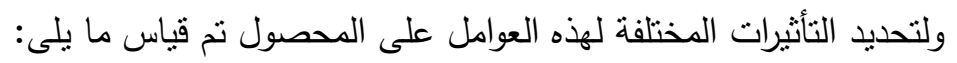

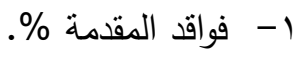
r- - طول الجزء المقطوع من الساق مع القرص (سم) وهو ما يسمى طول العنق. r- نسبة نزع الأقراص من الساق \% م ( بدون القطع ). ع- تحديد الاتجاه الأمثل للحصاد بالنسبة لاتجاه ميل الأقراص. 


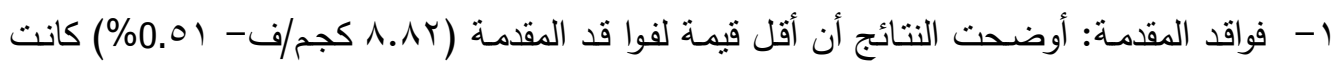

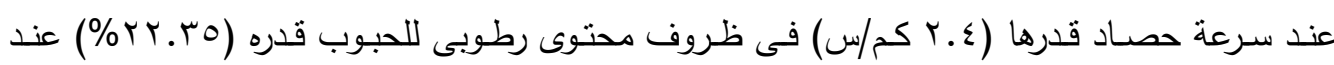

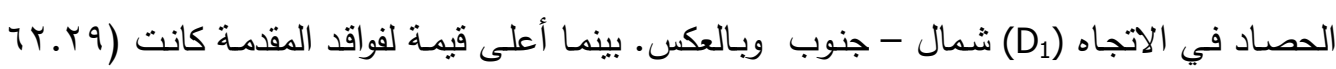

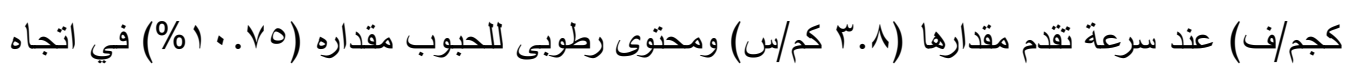

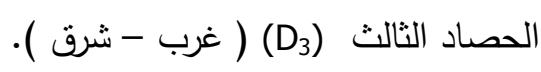

r- طول الجزء المقطوع من الساق مع القرص: (طول العنق): (سم) أوضحت التجارب أن أقل طول

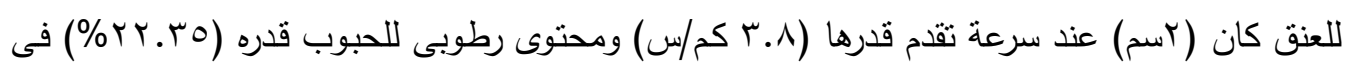

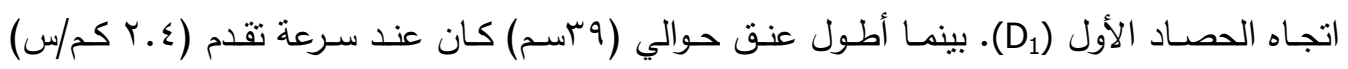

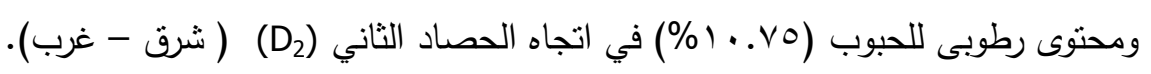

r- نسبة نزع الأقراص \%: أوضحت النتائج المتحصل عليها أن أقل نسبة لنزع الأقراص كانت (r\%)

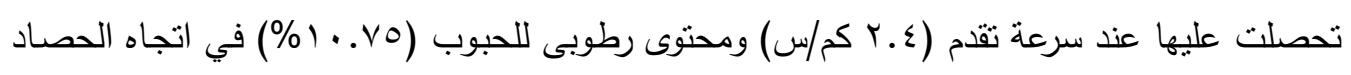

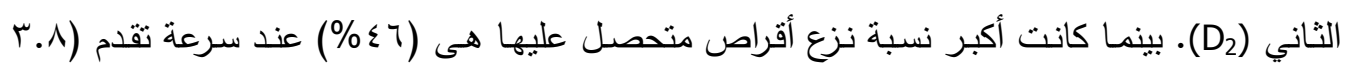

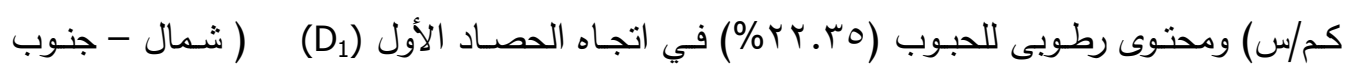
• وبالعكس ) ومن هذه النتائج تلاحظ أن أحسن اتجاه حصاد هو الاتجاه الأول (D) ( شمال - جنوب وبالعكس ). 